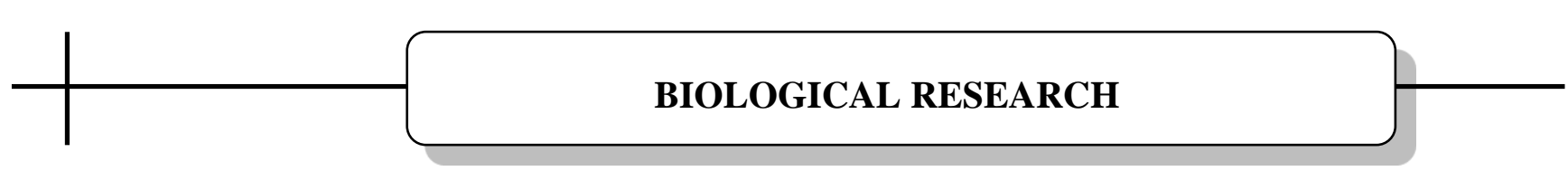

UDC 612.015.11:615.451.16:582.28-06:616.36-002-099:615.212]-092.9

DOI: 10.15587/2519-8025.2021.239920

\title{
THE STUDY OF OXIDATIVE STRESS INDICATORS IN RATS WITH A SIMULATED ACUTE HEPATITIS AND CORRECTION WITH A THICK EXTRACT FROM REISHI MUSHROOMS
}

\author{
Iryna Herasymets, Liudmila Fira, Ihor Medvid
}

The aim. To study the effect of a dry extract from reishi mushrooms on the activity of lipoperoxidation and oxidative modification of proteins under the conditions of a simulated paracetamol hepatitis in rats.

Materials and methods. The study was performed on white male rats. The animals were divided into 10 groups, each included 6 animals. Acute hepatitis was simulated by the intragastric administration of paracetamol in the dose of 1250 $\mathrm{mg} / \mathrm{kg}$ once per day (for 2 days). Correction of the pathology induced was performed with a dry extract of reishi mushrooms in the dose of $100 \mathrm{mg} / \mathrm{kg}$ of the body weight. The reference drug "Silybor" was administered in the dose of 20 $\mathrm{mg} / \mathrm{kg}$ of the animal body weight. On Day 3, 7 and 10 from the beginning of the lesion, rats were euthanized using sodium barbamyl. The liver homogenate and blood serum were used for the studies. The activity of free radical oxidation processes under the conditions of acute toxic hepatitis and after the introduction of corrective factors was assessed by superoxide dismutase, catalase activity, the content of TBA-AP and OMP products.

Results and discussion. The development of acute paracetamol hepatitis in rats and damage of hepatocyte membranes are indicated by an increase in the content of TBA-active products, products of oxidative modification of neutral and basic proteins in the serum and liver of animals. Simultaneously, a decrease in the activity of catalase and superoxide dismutase was observed. After correction of the pathology induced with a dry extract of reishi mushrooms a significant increase in the activity of antioxidant enzymes, a decrease in the content of lipid peroxidation products and oxidative modification of proteins in the serum and liver of the affected animals were observed.

Conclusions. It has been experimentally proven that the use of dry extract of Reishi mushrooms in paracetamol hepatitis in rats caused a significant decrease in catalase and superoxide dismutase activity, a decrease in TBA-AP, neutral and basic 2,4-DNPH in the serum and liver of animals. The results of the research indicate an effective impact of reishi mushrooms dry extract on the normalization of lipoperoxidation, oxidative modification of proteins and antioxidant protection

Keywords: reishi mushrooms, paracetamol, hepatitis, dry extract, oxidative stress, antioxidant properties

\section{How to cite:}

Herasymets, I., Fira, L., Medvid, I. (2021). The study of oxidative stress indicators in rats with a simulated acute hepatitis and correction with a thick extract from reishi mushrooms. ScienceRise: Biological Science, 3 (28), 4-9. doi: http://doi.org/10.15587/2519-8025.2021.239920

\section{Introduction}

Reishi mushroom, or bracket fungi, is an edible medicinal mushroom. For its healing properties, known for centuries, reishi could be called as the "king of mushrooms". It has an anti-inflammatory effect, strengthens the immune system and mental health. In Eastern medicine, reishi is considered an adaptogenic plant. This means that this fungus helps the body fight stress, such as inflammation, exhaustion, damage to blood vessels and hormonal failure $[1,2]$. Studies confirm that reishi has antioxidant properties that help the body fight cancer, autoimmune diseases and heart disease, as well as allergic reactions and infections [3-5].
As an immunomodulator, reishi can restore hormonal balance, homeostasis and regulate the immune system, which helps fight tumors. It is scientifically confirmed that these fungi work as a substance that normalizes, regulates various functions of cells and systems, including endocrine, immune, cardiovascular, central nervous and digestive $[6,7]$. One of the most valuable properties of reishi is the absence of any side effects after its application. Studies show that when eating reishi mushrooms, many people experience an influx of energy, improved concentration and mood, as well as reduced pain, digestive problems and infectious inflammation $[1,8,9]$. 
The liver is one of the most important organs in the human body. It helps remove toxins from the body, absorb nutrients and purify the blood. Reishi mushrooms have an adaptogenic effect, improving liver function and preventing its diseases. They promote more efficient removal of harmful substances and bacteria, as well as strengthen the immune system. International studies confirm that due to its antioxidant properties, the reishi mushroom has a hepatoprotective effect in acute inflammation of the liver and blocks the immune response, slowing down the liver $[2,10,11]$.

The aim of the study is to study the effect of dry extract of reishi mushrooms on the activity of free radical processes and indicators of the antioxidant system under conditions of paracetamol hepatitis in rats.

\section{Materials and methods}

Dry extract of reishi mushrooms (DERM) was the subject of our research. This extract is made for the research by the Department of Chemistry of Natural Compounds of the National University of Pharmacy and standardized for steroid compounds in accordance with the requirements of the SPU.

The experiments were performed on 60 white male rats, weighing 180-210 g, which were provided with the standard diet of the vivarium of I. Horbachevsky Ternopil National Medical University. The research presented in this article was conducted in 2016-2018.

All experiments were performed in accordance with the rules of bioethics in accordance with the "European Convention for the Protection of Vertebrate Animals Used for Experimental and Other Scientific Purposes" [12].

Excerpt from the minutes of the 65th meeting of the commission on bioethics of the I. Horbachevsky Ternopil National Medical University of the Ministry of Health of Ukraine dated September 1, 2021.

Simulation of acute hepatitis is performed by administering paracetamol intragastrically at a dose of 1250 $\mathrm{mg} / \mathrm{kg} 1$ time per day for 2 days as a suspension in $2 \%$ starch gel solution. Correction of the induced pathology was performed with dry extract of reishi mushrooms, which was administered intragastrically 2 hours before the introduction of the toxicant and daily after the lesion at a dose of $100 \mathrm{mg} / \mathrm{kg}$ of body weight. Silybor (manufactured by LLC "Pharmaceutical Company "Zdorovya") was chosen as a comparison drug, which was administered according to the same scheme as the studied extract, at a dose of $20 \mathrm{mg} / \mathrm{kg}$ of rat body weight. The animals were grouped into 10 groups, each consisting of 6 animals: Group 1 - animals of intact control (IC); 2nd, $3 \mathrm{rd}$ and 4 th - rats treated with paracetamol, 3rd, 7th and 10th days of the study, respectively (control pathology $\mathrm{CP}$ ); 5th, 6th and 7th groups - affected rats, which were injected with reishi mushroom extract at a dose of $100 \mathrm{mg} / \mathrm{kg}$ body weight, 3rd, 7th and 10th days of the experiment, respectively $(\mathrm{CP}+\mathrm{DERM})$; the 8th, 9th and 10th groups of affected animals were intragastrically injected with Silybor, 3rd, 7th and 10th days of the study, respectively $(\mathrm{CP}+$ Silybor $)$.

On the 3rd, 7th and 10th day from the onset of the lesion, rats were euthanized using sodium barbamyl. Liver homogenate and serum were examined. Blood was taken from the hearts of animals. The activity of free radical oxidation processes in the affected rats of paracetamol after the introduction of corrective factors was assessed by the content of TBA-active products (TBA-AP) [13] and products of oxidative modification of proteins (OMP) [14, 15]. The state of the antioxidant system (AOS) was assessed by superoxide dismutase (SOD) [16] and catalase (Cat) activity [17].

The obtained results were subjected to statistical processing in the program STATISTICA 12. The significance of intergroup differences was determined using the criterion of rank sums of Wilcoxon and Mann-Whitney test. The results were considered reliable at $\mathrm{p} \leq 0.05[18,19]$.

\section{Results}

Studies indicate the activation of free radical oxidation processes under the action of paracetamol on the body of experimental animals with dysfunction of the antioxidant defence system due to intensive consumption of protective enzymes in detoxification reactions and disruption of their synthesis.

It was found that the introduction of paracetamol caused the activation of lipid peroxidation (LP) in serum and liver tissue, which is confirmed by a probable $(p \leq 0.05)$ increase in TBA-AP. Thus, this indicator against the group of intact control increased in the blood of affected animals by 2.2, 2.6 and 2.7 times on the 3rd, 7 th and 10th day of the experiment (Table 1).

Table 1

The content of TBA-AP in the serum $(\mu \mathrm{mol} / \mathrm{l})$ and liver $(\mu \mathrm{mol} / \mathrm{kg})$ of rats affected by paracetamol, and after application of reishi mushroom extract $(M \pm m ; n=60)$

\begin{tabular}{|c|c|c|c|c|c|c|}
\hline \multirow{2}{*}{\begin{tabular}{c} 
Group of ani- $\begin{array}{c}|c| \\
\text { mals }\end{array}$ \\
\cline { 2 - 7 }
\end{tabular}} & \multicolumn{2}{|c|}{ 3rd day } & \multicolumn{2}{|c|}{7 th day } & \multicolumn{3}{c|}{10 th day } \\
\cline { 2 - 7 } & $\begin{array}{c}\text { blood } \\
\text { serum }\end{array}$ & liver & $\begin{array}{c}\text { blood } \\
\text { serum }\end{array}$ & liver & $\begin{array}{c}\text { blood } \\
\text { serum }\end{array}$ & liver \\
\hline IC & $2.91 \pm 0.32$ & $16.77 \pm 0.68$ & $2.91 \pm 0.32$ & $16.77 \pm 0.68$ & $2.91 \pm 0.32$ & $16.77 \pm 0.68$ \\
\hline CP & $6.51 \pm 0.37^{*}$ & $25.03 \pm 0.94^{*}$ & $7.62 \pm 0.29^{*}$ & $27.72 \pm 0.91^{*}$ & $7.97 \pm 0.25^{*}$ & $28.77 \pm 1.20^{*}$ \\
\hline CP +Silybor & $4.75 \pm 0.25^{* *}$ & $21.32 \pm 0.96^{* *}$ & $5.33 \pm 0.56^{* *}$ & $22.20 \pm 1.05^{* *}$ & $4.88 \pm 0.35^{* *}$ & $23.11 \pm 1.08^{* *}$ \\
\hline CP +DERM & $4.07 \pm 0.33^{* *}$ & $20.06 \pm 0.96^{* *}$ & $4.98 \pm 0.28^{* *}$ & $21.74 \pm 1.04^{* *}$ & $4.33 \pm 0.26^{* *}$ & $19.56 \pm 1.09^{* *}$ \\
\hline
\end{tabular}

Note. * - probable changes between the rate of control and paracetamol-affected animals; ** - probable changes between the rate of paracetamol-affected and treated animals 
In the liver of rats, a similar tendency was observed to increase the content of TBA-AP after exposure to the toxicant. Administration of DERM to rats with acute hepatitis resulted in a probable reduction in serum TBA-AP by $37 \%, 35 \%$ and $46 \%$ on days 3,7 and 10 of the experiment against the affected animals, respectively. In the liver homogenate after DERM correction, a probable $(\mathrm{p} \leq 0.05)$ decrease in TBA- AP content by $20 \%, 22$ $\%$ and $32 \%$ on the 3rd, 7th and 10th days of hepatitis was observed, respectively, relative to the control pathology. The use of Silybor as a reference drug also had a positive effect on the studied serum and liver of animals with hepatitis.

Not only lipid, but also protein components of membranes undergo peroxidation processes, which causes changes in enzyme activity, disruption of nucleic acid synthesis and accumulation of toxic metabolic products.

The results of the study of OMP showed that in the serum and liver of rats after their defeat by paracetamol there is an increase in the content of 2,4-DNPH of neutral and basic nature (Table 2).

Table 2

Neutral 2,4-DNPH content ( $\mu \mathrm{mol} / \mathrm{g}$ protein) in the serum and liver of paracetamol-affected rats and after application of reishi mushroom extract $(\mathrm{M} \pm \mathrm{m} ; \mathrm{n}=60)$

\begin{tabular}{|c|c|c|c|c|c|c|}
\hline \multirow{3}{*}{$\begin{array}{l}\text { Group of ani- } \\
\text { mals }\end{array}$} & \multicolumn{6}{|c|}{ Indicators } \\
\hline & \multicolumn{2}{|c|}{ 3rd day } & \multicolumn{2}{|c|}{ 7th day } & \multicolumn{2}{|c|}{ 10th day } \\
\hline & $\begin{array}{l}\text { blood } \\
\text { serum }\end{array}$ & liver & $\begin{array}{l}\text { blood } \\
\text { serum }\end{array}$ & liver & $\begin{array}{l}\text { blood } \\
\text { serum }\end{array}$ & liver \\
\hline $\mathrm{IC}$ & $0.032 \pm 0.005$ & $0.075 \pm 0.005$ & $0.032 \pm 0.005$ & $0.075 \pm 0.005$ & $0.032 \pm 0.005$ & $0.075 \pm 0.005$ \\
\hline $\mathrm{CP}$ & $0.079 \pm 0.007 *$ & $0.121 \pm 0.007^{*}$ & $0.089 \pm 0.005^{*}$ & $0.137 \pm 0.007^{*}$ & $0.095 \pm 0.004 *$ & $0.148 \pm 0.007^{*}$ \\
\hline $\mathrm{CP}+$ Silybor & $0.060 \pm 0.008$ & $0.101 \pm 0.006$ & $0.061 \pm 0.006^{* *}$ & $0.100 \pm 0.007 * *$ & $0.050 \pm 0.005^{* *}$ & $0.103 \pm 0.005^{* *}$ \\
\hline $\mathrm{CP}+\mathrm{DERM}$ & $0.057 \pm 0.007$ & $0.093 \pm 0.007 * *$ & $0.050 \pm 0.006^{* *}$ & $0.082 \pm 0.009 * *$ & $0.042 \pm 0.004 * *$ & $0.086 \pm 0.009 * *$ \\
\hline
\end{tabular}

Note. * - probable changes between the rate of control and paracetamol-affected animals; ** - probable changes between the rate of paracetamol-affected and treated animals

As can be seen from Table 2, the content of 2,4DNPH of neutral character in the serum of the affected animals increased by $2.5,2.8$ and 3.0 times, respectively, on the 3rd, 7th and 10th day of the experiment on intact animals. A similar tendency to increase observed in the liver of experimental animals. After correction of the test extract determined a probable decrease in the content of 2,4-DNPH neutral in serum on the 7th day of hepatitis, in the liver of experimental animals reduction was observed on the 3rd day of the experiment. The content of 2,4DNPH of the main character (Table 3) probably increased in the serum of rats at all times of the study $(p \leq 0.05)$. In the liver of rats after paracetamol infection, the content of 2,4-DNPH of the main nature by the end of the experiment increased 2.8 times compared to the group of animals of control pathology.

Table 3

The content of 2,4-DNPH of the main nature ( $\mu \mathrm{mol} / \mathrm{g}$ protein) in the serum and liver of rats affected by paracetamol, and after application of Reishi mushroom extract $(M \pm m ; n=60)$

\begin{tabular}{|c|c|c|c|c|c|c|}
\hline \multirow{3}{*}{$\begin{array}{c}\text { Group of ani- } \\
\text { mals }\end{array}$} & \multicolumn{6}{|c|}{ Indicators } \\
\hline & \multicolumn{2}{|c|}{ 3rd day } & \multicolumn{2}{|c|}{ 7th day } & \multicolumn{2}{|c|}{ 10th day } \\
\hline & blood & liver & blood & liver & blood & liver \\
\hline IC & $0.011 \pm 0.002$ & $0.037 \pm 0.003$ & $0.011 \pm 0.002$ & $0.037 \pm 0.003$ & $0.011 \pm 0.002$ & $0.037 \pm 0.003$ \\
\hline $\mathrm{CP}$ & $0.039 \pm 0.005^{*}$ & $0.080 \pm 0.004 *$ & $0.053 \pm 0.005^{*}$ & $0.095 \pm 0.008^{*}$ & $0.063 \pm 0.004 *$ & $0.104 \pm 0.009 *$ \\
\hline $\mathrm{CP}+$ Silybor & $0.034 \pm 0.003$ & $0.067 \pm 0.006$ & $0.035 \pm 0.004 * *$ & $0.054 \pm 0.004 * *$ & $0.032 \pm 0.003 * *$ & $0.052 \pm 0.005^{* *}$ \\
\hline $\mathrm{CP}+\mathrm{DERM}$ & $0.026 \pm 0.004$ & $0.050 \pm 0.004 * *$ & $0.022 \pm 0.004 * *$ & $0.044 \pm 0.006^{* *}$ & $0.018 \pm 0.004^{* *}$ & $0.043 \pm 0.005^{* *}$ \\
\hline
\end{tabular}

Note. * - probable changes between the rate of control and paracetamol-affected animals; ** - probable changes between the rate of paracetamol-affected and treated animals

The correction with DERM caused a decrease in the content of 2,4-DNPH of the main character in the serum and liver of rats against the affected animals, the values of which were almost close to the level of intact animals. The use of the comparison drug was also effective.

Under its influence, the content of 2,4-DNPH of the main character in the serum of the liver of animals with hepatitis decreased by $71 \%$ and $59 \%$, respective$1 y$, on the 10th day of the experiment against the affected animals.

The body's protective mechanism that prevents the development of oxidative stress is the antioxidant system. Catalase (Cat) and superoxide dismutase (SOD) play a key role in regulating the level of free radicals, including reactive oxygen species.

Under conditions of paracetamol hepatitis in rats, a probable decrease in SOD activity in the serum and liver of animals against control was observed (Tab. 4), which indicates a weakening of the enzymatic protection of cells from reactions of free radical oxidation of lipids. Inhibition of SOD activity may be due to depletion of the enzyme reserve due to its more intensive use to neutralize free radicals, the formation of which is enhanced in acute hepatitis. 
Table 4

Superoxide dismutase activity in serum and liver (mcat/g protein) of rats affected by paracetamol and after application of reishi fungi extract $(\mathrm{M} \pm \mathrm{m} ; \mathrm{n}=60)$

\begin{tabular}{|c|c|c|c|c|c|c|}
\hline \multirow{2}{*}{$\begin{array}{c}\text { Group of ani- } \\
\text { mals }\end{array}$} & \multicolumn{2}{|c|}{ 3rd day } & \multicolumn{2}{c|}{ Ithdicators } \\
\cline { 2 - 7 } & blood serum & liver & blood serum & liver & \multicolumn{3}{c|}{ blood serum } & liver \\
\hline IC & $62.40 \pm 1.76$ & $52.08 \pm 1.66$ & $62.40 \pm 1.76$ & $52.08 \pm 1.66$ & $62.40 \pm 1.76$ & $52.08 \pm 1.66$ \\
\hline CP & $43.72 \pm 1.73^{*}$ & $39.49 \pm 1.85^{*}$ & $41.33 \pm 1.15^{*}$ & $37.42 \pm 1.89^{*}$ & $40.07 \pm 1.10^{*}$ & $37.86 \pm 1.18^{*}$ \\
\hline CP + Silybor & $48.04 \pm 2.86$ & $41.28 \pm 1.57$ & $50.86 \pm 2.36^{* *}$ & $43.36 \pm 2.25$ & $52.94 \pm 1.55^{* *}$ & $44.81 \pm 1.89^{* *}$ \\
\hline CP + DERM & $52.46 \pm 1.77^{*} *$ & $44.61 \pm 1.86$ & $54.66 \pm 1.85^{* *}$ & $45.93 \pm 1.97^{* *}$ & $56.26 \pm 1.36^{* *}$ & $47.32 \pm 2.00^{* *}$ \\
\hline
\end{tabular}

Note: * - probable changes between the rate of control and paracetamol-affected animals; ** - probable changes between the rate of paracetamol-affected and treated animals

After application of DERM SOD-activity increased in the blood of rats by $20 \%, 32 \%$ and $40 \%$ on the $3 \mathrm{rd}, 7 \mathrm{th}$ and $10 \mathrm{th}$ day of the experiment against the affected animals, respectively. With the use of the comparison drug, a probable increase in enzyme activity in the serum of rats was observed by $23 \%$ and $32 \%$ on the 7 th and 10th day of the study.

Regarding the SOD activity in the liver homogenate of rats affected by paracetamol, on the 10th day of the study it decreased almost 1.4 times against the control group. Following administration of DERM to animals, the enzyme activity was likely to increase on day
7 of the animal experiment with hepatitis (CP). With the use of Silybor, positive changes in SOD activity were observed on the 10th day of the experiment $(\mathrm{p} \leq 0.05)$.

Because SOD utilizes reactive oxygen species with the formation of hydrogen peroxide, it is important for cell viability to balance SOD and the enzyme that oxidizes hydrogen peroxide, catalase.

Defeat of animals with paracetamol leads to a probable decrease in catalase activity in the serum and liver of rats on the 3rd day of the study against the intact group (Table 5).

Table 5

Catalase activity in the serum (mcat/l) and liver (mcat $/ \mathrm{kg}$ ) of rats affected by paracetamol, and after application of reishi mushroom extract $(\mathrm{M} \pm \mathrm{m} ; \mathrm{n}=60)$

\begin{tabular}{|c|c|c|c|c|c|c|}
\hline \multirow{3}{*}{$\begin{array}{l}\text { Group of ani- } \\
\text { mals }\end{array}$} & \multicolumn{6}{|c|}{ Indicators } \\
\hline & \multicolumn{2}{|c|}{ 3rd day } & \multicolumn{2}{|c|}{ 7th day } & \multicolumn{2}{|c|}{ 10th day } \\
\hline & blood & liver & blood & liver & blood & liver \\
\hline $\mathrm{IC}$ & $4.43 \pm 0.36$ & $7.16 \pm 0.22$ & $4.43 \pm 0.36$ & $7.16 \pm 0.22$ & $4.43 \pm 0.36$ & $7.16 \pm 0.22$ \\
\hline $\mathrm{CP}$ & $1.71 \pm 0.17^{*}$ & $3.24 \pm 0.31 *$ & $1.60 \pm 0.11 *$ & $3.05 \pm 0.28 *$ & $1.41 \pm 0.18 *$ & $2.86 \pm 0.36^{*}$ \\
\hline $\mathrm{CP}+$ Silybor & $2.03 \pm 0.26$ & $4.20 \pm 0.30$ & $2.90 \pm 0.26 * *$ & $4.94 \pm 0.39 * *$ & $3.11 \pm 0.18 * *$ & $5.54 \pm 0.50 * *$ \\
\hline $\mathrm{CP}+\mathrm{DERM}$ & $2.54 \pm 0.28$ & $5.21 \pm 0.19 * *$ & $3.53 \pm 0.15 * *$ & $5.85 \pm 0.30 * *$ & $3.65 \pm 0.27 * *$ & $6.20 \pm 0.41 * *$ \\
\hline
\end{tabular}

Note: * - probable changes between the rate of control and paracetamol-affected animals; **-probable changes between the rate of paracetamol-affected and treated animals

Under conditions of correction of the induced pathology of DERM and the comparison drug, a tendency to increase the catalase activity of blood serum and liver of rats in animals with acute untreated hepatitis was observed.

\section{Discussion of research results}

The development of many pathological conditions occurs by a free radical mechanism, which at the cellular level is characterized by increased production of free radicals, among which a special place belongs to the active forms of oxygen (AFO) [20]. AFOs could cause lipid peroxidation (LP) and disrupt the bilayer arrangement of membrane lipids, accompanied by inactivation of membranebound receptors and enzymes, increase tissue permeability. Most lipid peroxidation products are able to inactivate cellular proteins by blocking or breaking bonds [21].

To determine the content of one of the indicators of LP, TBA-AP, we studied in the serum and liver of rats affected by paracetamol. Throughout the study, there was a progressive increase in TBA-AP content in both tissues, the maximum values of which were recorded on the 10th day of the experiment. Our experimental data are consistent with the results of studies by other authors, which showed that paracetamol poisoning activates the processes of free radical oxidation in animals $[21,22]$.

It is known from the literature that under conditions of oxidative stress and excessive generation of AFO, processes of uncontrolled modification of proteins develop, which cause their fragmentation, denaturation, and the formation of primary amino acid radicals, which then interact with neighbouring amino acid residues. In general, a rather complex picture of the damaging effect of AFO on protein macromolecules is created. All this leads to the loss of proteins of their biological activity and disruption of metabolic, in particular regenerative processes [20].

OMP is an early marker of cell damage during free radical oxidation and a trigger for the destruction of lipids, nucleic acids and other molecules under the influence of oxidative stress [15].

An experimental study of OMP showed that in the serum and liver of rats after their defeat with paracetamol 
there is an increase in the content of 2,4-DNPH of neutral and basic nature. This may be due to the interaction of proteins with reactive oxygen species, with their subsequent modification. When comparing the indicators of lipoperoxidation with the indicators of oxidative modification of proteins, there was a tendency to increase them after the defeat of paracetamol. This confirms the relationship and interdependence of these processes in the development of pathological conditions, which is given in other experimental works [21, 22].

One of the reasons for the activation of lipoperoxidation and oxidative modification of proteins in pathology may be a violation of the body's antioxidant defence system, which controls the passage of all free radical reactions and ensures the normal functioning of the body and its vital functions.

The most powerful natural antioxidant and enzyme of the first link of anti- radical protection is SOD, so the indicators of its activity indicate the depth of tissue damage and metabolic disorders under the influence of oxidative stress. The decrease in the activity of this enzyme in blood serum may be due to the fact that paracetamol induces free radical oxidation processes, which can change the conformation of the apoenzyme by binding sulfhydryl groups and oxidative modification of the active center of holoenzyme $[15,23]$. The results of the study indicate a significant decrease in enzyme activity on the 7th and 10th day of development of paracetamol hepatitis [10].

Inhibition of SOD activity, apparently, may be due to significant depletion of the pool of enzymes due to their increased use to neutralize free radicals, the production of which is significantly intensified in animals under the influence of paracetamol.

On the other hand, it is known about the direct effect of reactive oxygen species on the degree of oxidation of metal ions in the active centers of enzymes, which causes inhibition of their functioning [20]. Another reason for the decrease in superoxide dismutase activity may be the accumulation of hydrogen peroxide, which is a superoxide dismutase inhibitor [23].

Infection of animals with paracetamol caused a decrease in catalase activity in serum and liver, which may be associated with depletion of the body's defence systems that maintain homeostasis, as well as impaired liver protein-synthesizing function in animals affected by the toxicant. The obtained data are consistent with the literature [21, 24], which shows that one of the reasons for the decrease in enzyme activity may be the degradation of free and membrane-bound endoplasmic reticulum ribosomes, which are responsible for protein synthesis.
Decreased catalase activity in rats contributes to the accumulation of a toxic product of dismutation of superoxide anion radical - hydrogen peroxide and indicates rapid depletion of the antioxidant defence system under conditions of toxic damage to the body, which leads to damage of enzyme molecules by peroxidation products. This is confirmed in our experiments.

Study limitation. There is a need to use drugs with antioxidant properties under these conditions. Promising in this regard is the study of the pharmacological activity of extracts from reishi fungi.

There are insufficient data in the literature on the membrane-protective, sorbent and antimicrobial properties of reishi fungi, therefore, this is the subject of our further research.

Prospects for further research. The obtained experimental data provide a basis for further study of dry extract of reishi mushrooms for introduction into practical medicine and pharmacy, which will expand the arsenal of antioxidants and hepatoprotective agents, increase the effectiveness of prevention and treatment of pathological conditions that activate oxidative processes in the body.

\section{Conclusions}

Intragastric administration of paracetamol to animals has been shown to cause an increase in the content of lipid peroxidation products and oxidative modification of proteins - TBA-AP, 2,4-dinitrophenylgidazones, against the background of reduced SOD - and catalase activity in the serum and liver of animals against the control group. During the correction of toxic hepatitis DERM and the reference drug, a probable decrease in the content of TBA-AP, 2,4dinitrophenylgidazones and an increase in superoxide dismutase and catalase activity was observed in animals that were not treated.

Correction of simulated hepatitis in case of DERM administration against the comparison drug has a more pronounced positive effect on reducing the intensity of LP and OMP processes, as well as increasing the activity of SOD and catalase in the serum and liver of animals. This indicates the antioxidant properties of the studied extract and determines the feasibility of its use in the treatment of liver disease.

\section{Conflict of interests}

The authors declare that they have no conflicts of interest.

Financing

The study was performed without financial support.

\section{References}

1. Herasymets, I. I., Fira, L. S., Medvid, I. I. (2019). Parameters of the experimental extract of reishi mushrooms acute toxicity determination. Fitoterapia, 3 (3), 46-49. doi: http://doi.org/10.33617/2522-9680-2019-3-46

2. Kyslychenko, V. S., Harnyk, T. P., Zhuravel, I. O. (2013). Hryby yak perspektyvna syrovyna dlia zastosuvannia v medytsyni. Fitoterapiia. Chasopys, 1, 31-35.

3. Veljović, S., Veljović, M., Nikićević, N., Despotović, S., Radulović, S., Nikšić, M., Filipović, L. (2017). Chemical composition, antiproliferative and antioxidant activity of differently processed Ganoderma lucidum ethanol extracts. Journal of Food Science and Technology, 54 (5), 1312-1320. doi: http://doi.org/10.1007/s13197-017-2559-y 
4. Liang, Z., Yi, Y., Guo, Y., Wang, R., Hu, Q., Xiong, X. (2014). Chemical Characterization and Antitumor Activities of Polysaccharide Extracted from Ganoderma lucidum. International Journal of Molecular Sciences, 15 (5), 9103-9116. doi: http://doi.org/10.3390/ijms15059103

5. Herasymets, I., Fira, L., Medvid, I. (2019). Study of the Reishi mushrooms dry extract hepatoprotective properties. Ukrainian Biopharmaceutical Journal, 4 (61), 28-34. doi: http://doi.org/10.24959/ubphj.19.232

6. Vetchinkina, Ye., Shyrokov, A. A., Bucharskaia, A. B. (2015). Vyyavlenie protivoopukholevoy aktivnosti gribnogo mitseliya i plodovikh tel. Bazidialnykh gribov. Uspekhi meditsinskoy mikolohii, 14 (14), 462-471.

7. Zeng, P., Guo, Z., Zeng, X., Hao, C., Zhang, Y., Zhang, M. et. al. (2018). Chemical, biochemical, preclinical and clinical studies of Ganoderma lucidum polysaccharide as an approved drug for treating myopathy and other diseases in China. Journal of Cellular and Molecular Medicine, 22 (7), 3278-3297. doi: http://doi.org/10.1111/jcmm.13613

8. Wang, J., Cao, B., Zhao, H., \& Feng, J. (2017). Emerging Roles of Ganoderma Lucidum in Anti-Aging. Aging and Disease, 8 (6), 691-707. doi: http://doi.org/10.14336/ad.2017.0410

9. Wu, D.-T., Deng, Y., Chen, L.-X., Zhao, J., Bzhelyansky, A., Li, S.-P. (2017). Evaluation on quality consistency of Ganoderma lucidum dietary supplements collected in the United States. Scientific Reports, 7 (1). doi: http://doi.org/10.1038/s41598017-06336-3

10. Kalko, K. O., Drohovoz, S. M. (2017). Circadian dependence of Antral hepatoprotective activity on the model of acute paracetamol-induced hepatitis in rats. Farmakolohiia ta likarskatoksykolohiia, 2 (54), 62-68.

11. Zmitrovich, I. V. (2014). Griby posylayut signaly. Planetahribov, 2 (6), 21-27.

12. Gross, D., Tolba, R. H. (2015). Ethics in Animal-Based Research. European Surgical Research, 55 (1-2), 43-57. doi: http://doi.org/10.1159/000377721

13. Lushchak, V. I., Bahniukova, T. V., Lushchak, O. V. (2004). Pokaznyky oksydatyvnoho stresu. Tiobarbituraktyvni produkty i karbonilni hrupy bilkiv. Ukrainskyibiokhimichnyi zhurnal, 26, 136-141.

14. Dubinina, Ye. Ye. (2001). Okislitelniy stress i okislitelnaya modifikatsiya belkov. Med. Chemistry, 2, 5-12.

15. Dubinina, Ye. Ye. (2001). Rol aktivnykh form kisloroda v kachestve signalnykh molekul v metabolizme tkaney pri sostoyanii okislitelnogo stressa. Voprosy meditsinskoi khimii, 47 (6), 561-581.

16. Babizhayev, M. A. (2011). Mitochondria induce oxidative stress, generation of reactive oxygen species and redox state unbalance of the eye lens leading to human cataract formation: disruption of redox lens organization by phospholipid hydroperoxides as a common basis for cataract. Cell Biochemistry and Function, 29 (3), 183-206. doi: http://doi.org/10.1002/cbf.1737

17. Koroliuk, M. A., Ivanova, L. I., Maiorova, I. H. (1988). Metod opredeleniya aktivnosti katalazy. Laboratornoe delo, 1, 16-19.

18. Shelamova, M. A., Insarova, N. I., Lieshchienko, V. H. (2010). Statisticheskii analiz miediko-biologichieskikh dannykh s ispolzovaniiem programmy EXCEL. Minsk: BGMU, 96.

19. Jannot, A.-S., Agoritsas, T., Gayet-Ageron, A., Perneger, T. V. (2013). Citation bias favoring statistically significant studies was present in medical research. Journal of Clinical Epidemiology, 66 (3), 296-301. doi: http://doi.org/10.1016/j.jclinepi.2012.09.015

20. Lavryshyn, Y. Y., Varkholyak, I. S., Martyschuk, T. V., Guta, Z. A., Ivankiv, L. B., Paladischuk, O. R. et. al. (2016). The biological significance of the antioxidant defense system of animal's body. Scientific Messenger LNUVMBT named after S.Z. Gzhytskyj, 18 (2 (66)), 100-111.

21. Diorditsa, Ya. (2019). Antioxidant system activity in liver of ratsunder conditions of acute hepatitis during correctionwith antioxidant complexes. Visnyk of the Lviv University. Series Biology, 81, 12-20.

22. Drogovoz, S. M., Mishchenko, O. M., Kalko, K. O., Bogdan, N. S., Gerush, O. V. (2019). Circadian developmental rhythms of the experimental paracetamol hepatitis and the effect of hepatoprotectors on the activity of pro-oxidative / antioxidant and cytolytic processes. Clinical pharmacy, 23 (2), 15-24. doi: http://doi.org/10.24959/cphj.19.1485

23. Ryeznikov, O. H., Polumbryk, O. M., Baljon, Ya. H. (2014). Pro- and antioxidant systems and pathological processes in humans. Visn. NAN Ukrainy, 10, 17-29.

24. Kravchenko, V. M., Shovkova, Z. V., Senyuk, I. V., Shovkova, O. V. (2020). The study of lipotropic action of extract from fruit prunus domestica «Prunofit» byanimal models of alcoholic liver diseases. Farmatsevtychnyi Zhurnal, 6, 86-91. doi: http://doi.org/10.32352/0367-3057.6.20.09

Received date 25.05.2021

Accepted date 12.07.2021

Published date 30.09.2021

Iryna Herasymets, $\mathrm{PhD}$, Associate Professor, Department of Pharmacology with Clinical Pharmacology, I. Ya. Horbachevsky Ternopil National Medical University, Voli sq., 1, Ternopil, Ukraine, 46001

Liudmila Fira*, Doctor of Biological Sciences, Professor, Head of Department, Department of Pharmacy, I. Ya. Horbachevsky Ternopil National Medical University, Voli sq., 1, Ternopil, Ukraine, 46001

Igor Medvid, PhD, Associate Professor, Department of Microbiology, Virology and Immunology, I. Ya. Horbachevsky Ternopil National Medical University, Voli sq., 1, Ternopil, Ukraine, 46001

*Corresponding author: Iryna Herasymets, e-mail: irunaherasymets@gmail.com 